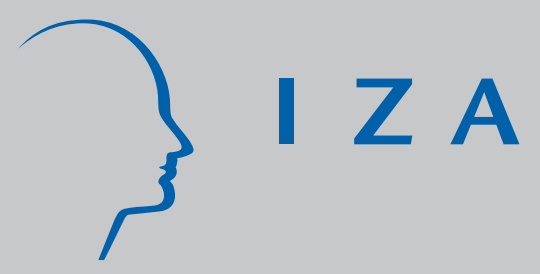

IZADP No. 1829

A Tale of Parallel Integration Processes.

A Gravity Analysis of EU Trade with Mediterranean and Central and Eastern European Countries

Anna Ferragina

Giorgia Giovannetti

Francesco Pastore

October 2005 


\title{
A Tale of Parallel Integration Processes. A Gravity Analysis of EU Trade with Mediterranean and Central and Eastern European Countries
}

\author{
Anna Ferragina \\ ISSM-CNR \\ Giorgia Giovannetti \\ University of Florence \\ and Italian Foreign Trade Commission \\ Francesco Pastore \\ Seconda Università di Napoli \\ and IZA Bonn \\ Discussion Paper No. 1829 \\ October 2005
}

IZA

P.O. Box 7240

53072 Bonn

Germany

Phone: +49-228-3894-0

Fax: +49-228-3894-180

Email: iza@iza.org

Any opinions expressed here are those of the author(s) and not those of the institute. Research disseminated by IZA may include views on policy, but the institute itself takes no institutional policy positions.

The Institute for the Study of Labor (IZA) in Bonn is a local and virtual international research center and a place of communication between science, politics and business. IZA is an independent nonprofit company supported by Deutsche Post World Net. The center is associated with the University of Bonn and offers a stimulating research environment through its research networks, research support, and visitors and doctoral programs. IZA engages in (i) original and internationally competitive research in all fields of labor economics, (ii) development of policy concepts, and (iii) dissemination of research results and concepts to the interested public.

IZA Discussion Papers often represent preliminary work and are circulated to encourage discussion. Citation of such a paper should account for its provisional character. A revised version may be available directly from the author. 


\section{ABSTRACT}

\section{A Tale of Parallel Integration Processes. A Gravity Analysis of EU Trade with Mediterranean and Central and Eastern European Countries ${ }^{*}$}

Despite the EU emphasis on the 1995 Barcelona process, trade integration with the Mediterranean (MED) countries is still underdeveloped. To contrast the success of EU integration with MED countries and that with the new EU members, we compute the trade potential of these EU partners from 1995 to 2002 using an "out-of-sample" methodology. The coefficients are taken from different panel estimators of the gravity equation relative to intraEU trade. Our analysis suggests the existence of sizeable, unexploited trade potential with both groups of partners, although the ratio of potential to actual trade with the MED countries is much larger (from 1.7 to 2.5 times), more dispersed and stable compared to that with the CEECs. Moreover, the potential tends to converge to actual trade in a much longer time in the case of MED countries.

JEL Classification: $\quad$ C23, F15, F17, P45, P52

Keywords: $\quad$ MED agreements, EU eastward enlargement, gravity equation, trade potential

Corresponding author:

Anna Ferragina

ISSM-CNR

Via Pietro Castellino 111

Napoli

Italy

Email: annamaria.ferragina@issm.cnr.it

\footnotetext{
* This paper has been presented at the European Trade Study Group, University of Nottingham, 9-11 September 2004; at the CNR Study Group on "International Economics and Development" Università Commerciale Luigi Bocconi, Milan, 5-6 November 2004; and at the Romanian Academy of Science, 10 November 2004. We thank Paolo Epifani, Rodolfo Helg, Lelio lapadre, Paolo Malanima, Mariana Nicolae, Lucia Tajoli for useful comments. However, the usual disclaimer applies.
} 


\section{Introduction}

In the last decade, gravity models have been extensively used to forecast potential bilateral trade relations and integration effects between EU (or OECD) countries and the former CMEA members, but rarely in the case of trade relations between the EU and the South Mediterranean countries ${ }^{1}$ (MED from now). Persistent high barriers to trade ${ }^{2}$ along with remarkable social and economic differences between the two shores of the Mediterranean have made less optimistic the perspectives of enhanced financial and commercial integration compared to that with Eastern Europe. The emphasis and the strong commitment on the Eastward enlargement of the EU in the second half of the nineties, according to some observers, even resulted in a sort of "crowding out" of the Euro-Mediterranean partnership launched in $1995^{3}$.

The aim of this paper is to provide an assessment of the relative success of the Europe Agreements $(\mathrm{EAs})^{4}$ versus the Mediterranean Association Agreements (MAAs from now), using the same modelling

1 Section two reports the results of the existing literature (see also Brenton and Gros, 1997; Fontagnè et al., 1999; Greenaway and Milner, 2002). Only few studies analyzed the Arab potential of trade with advanced economies and with the rest of the Arab world, but without focusing on the issue of Euro-Mediterranean integration (see IMF, 2002; Miniesy, Nugent and Yousef, 2004; Hassan, 1998; Al-Atrash and Yousef, 2000).

2 The average rate of protection in the MED countries is high, at $17.5 \%$ for all products, except agricultural products and services. In the case of Morocco, the same figure was 21\% in 1997 and became $31 \%$ in 2001. It was constant at 20\% in the case of Tunisia and above 20\% in the case of Egypt over the last ten years (Femise, 2002). These figures compare with a rate of $5.2 \%$ in the case of CEECs.

3 The Barcelona process started at the European Council in 1995. Association Agreements have been signed with Malta (1971) and Cyprus, (1972), Tunisia and Israel (1995), Morocco (1996), Jordan (1997), Palestine (1997), Egypt (2001), Lebanon and Algeria (2002), while the conclusion of an agreement was reached with Syria at the end of 2003. They have all entered into force except for Lebanon, Algeria and Syria. Since 2004 Malta and Cyprus have become member states of the EU. Libya has the status of observer and Syria is still in the stage of ratification. The application of these agreements has had a new acceleration with the European Council of Thessalonica in June 2003. Liberalisation consists of a gradual levying of tariffs and trade barriers for manufacturing products and of a gradual liberalisation for agricultural products and services. it should be noted that the EU has opened its markets to MED long before the Barcelona agreement, gradually reducing tariffs for a large number of industrialised products. As a result, liberalisation has essentially regarded tariffs imposed by the Mediterranean countries on goods imported from Europe

4 The Europe Agreements (EAs) were initiated by the EU with each CEEC separately. The first agreements with Poland, Hungary and Czechoslovakia were signed in December 1991 and came into force only in 1994. On 1st February 1993, similar agreements were signed with Bulgaria, Romania as well as the newly established countries of the Czech Republic and Slovakia. They came into force in 1995. In 1998, EAs were implemented with the three Baltic States, followed by Slovenia on 1st February 1999. The EAs were aimed at fostering trade integration, but also the political dialogue and cultural and economic cooperation between the partners, while providing a basic outline for the gradual EU accession of CEECs. Over the period before the agreements came into force, Interim Agreements provided for an anticipated and temporary application of trade provisions. Their aim was to establish a free trade area for industrial goods for ten years on a reciprocal, but asymmetric basis: the EU had to remove its trade barriers more quickly than the CEECs. This led to the total removal of all tariff barriers on industrial products from the EU on 1st January 2002. However, for some "sensitive" industrial sectors a special discipline was created, 
strategy and type of data. The structure of the MAAs is analogous to the EAs under many respects and were built almost over the same span of time. This analysis aims at answering three main questions: 1) What amount of trade could be achieved with these two groups if the trade elasticity with respect to economic and geographic variables (relative mass, physical distance, common language, common land border, colony links) were like those achieved in intra-EU trade (trade potential)? 2) Do we observe a reduction of the gap between potential and actual trade over the two liberalisation processes (trade creation)? 3) What would be the timing for convergence to the potential for the two areas if integration would be pushed further (convergence)?

Gravity analysis is used to measure the different speed of trade integration of the EU with the two areas now mentioned. This is the best alternative when intertemporal extrapolation of trade patterns cannot be based on historical trade performance, as it is the case of both CEECs and MED due to their past economic isolation, distorted pricing structures, state intervention, scant international openness and recent transition from a planned to a market economy.

From a methodological point of view, this study differs from previous ones on CEECs and MED, because it uses a panel data specification of the gravity model and an "out-of-sample” computation to estimate trade potential ${ }^{5}$. In other words, we use the parameters extracted from a gravity equation of intra-EU bilateral trade flows to predict trade potential between five EU members (Italy, Germany, France, UK, Spain) and, respectively, MED and CEE countries. This approach implies some overestimation of trade potential, since a long time is necessary for new EU members, not to say of MED countries, to reach the same degree of integration that already exists among the EU-15. However, though very common in the relevant literature, an in-sample method of estimation of potential trade is not a proper one as it does not allow to disentangle to what extent the results depend on the amount of trade not yet exploited between the two partners under investigation rather than on the fact that the model adopted is unable to explain trade.

The results, which are remarkably stable across different specifications and estimation methods, suggest the existence of substantial unexploited trade between the EU and both the areas considered.

in particular for textiles, iron and steel, car industry (only for Poland) and a much more gradual liberalization was applied to agricultural goods and fisheries (EC, 1997). 
The gap is especially sizeable in the case of EU imports from the two areas. However, our estimates suggest that while the ratio of potential to actual trade with the MED countries is between 3.5 and 5, that with CEECs is between 2.0 and 2.6. Moreover, while the gap was recently narrowing in EU exports and imports with CEECs, approaching 2 in some cases (the Czech Republic, Hungary and Romania), the gap with MED economies is highly dispersed and rising. Finally, a prediction of the possible evolution of actual trade based on the World Bank forecasts regarding GDP growth of the countries considered suggests that the time necessary to reach the potential range between an average of 45 in the case of CEECs and of more than 100 years in the case of MED economies.

While this finding could be expected for the MEDs, it contrasts with previous ones relative to trade with CEECs, which suggested that trade potential was almost fully exploited already in 1992. The differences might depend on the fact that: a) this study focuses on intra-EU trade, rather than on trade with a larger, but less homogeneous group of countries, as a reference to estimate the elasticity of trade determinants with MED and CEECs; b) it applies an out-of-sample method to compute potential trade; c) it concentrates on a later period, 1995-2002, when GDP in most CEECs was rapidly increasing.

This paper is organised as follows. Section 2 contains a survey of the literature. Section 3 presents the econometric modelling. Section 4 sketches out the recent evolution of trade patterns and provides the estimates of the ratio between potential and actual trade for MED and CEECs and of the time necessary for convergence. The concluding remarks summarise the main findings and discuss some policy implications.

\section{A survey of the literature}

The gravity model has been frequently adopted to analyse trade flows and has proved successful in a variety of contexts. The general idea behind it comes from the gravity theory in physics, from which it derives its name. In the context of international trade the physical bodies are the exporting and importing countries, and the sizes of their economies are their masses. The larger are the economies of the countries involved, the larger is the volume of their trade. However, distance causes a resistance to trade, because of transportation and delivery costs, as well as of time lags between order and delivery, among

5 To our knowledge, only Baldwin (1994), Gros and Gonciarz (1996), Mathyas (1997) and Egger (2000; and 
other reasons. Additional trade resistance factors are import tariffs, border controls, quantitative restrictions, which represent indeed artificial trade costs ${ }^{6}$.

Gravity models have been frequently used over the past decade also to evaluate integration of CEECs in the EU (in particular for the 10 candidate countries), the impact this might have in terms of trade potential, and the ratio with the actual level of trade.

The results of these studies are mixed, depending on the period considered, the econometric specification and estimator adopted, as well as on the computation method used to calculate trade potential. The literature of the early 1990s predicts a sizeable increase of trade exchanges between EU and the CEECs. Wang and Winters (1992) find that East-East trade was large in 1985, while East-West trade was only a fraction of what it would have been in an integrated Europe. Hamilton and Winters (1992) adopt a similar approach, finding that trade within the former Soviet Union and the Eastern Europe bloc (SUEE) was static or falling, while trade with Western Europe might increase by up to five times. Baldwin (1994) finds that potential EU12-CEE exports and imports are twice the actual 1989 exports and imports.

Later studies, which have used data on the early transition period to estimate trade potential, support different conclusions. Most of them suggest that the actual integration between Eastern and Western countries is high and above the potential, which indicates that adjustment was already over in the early '90s (Gros and Gonciarz, 1996; Brenton and Di Mauro, 1999; Nilsson, 2000). For instance, Gros and Gonciarz (1996) correct Baldwin's estimates on the grounds that he used a GDP which was overvalued because it was calculated on pre-transition data (the per capita GDP used by Baldwin was much higher than the 1992 GDP for CEECs). Combining the parameters from Baldwin (1994) with the 1992 data on GDP, Gros and Gonciarz end up with a downward revision of Baldwin's projections of CEE-EU trade. Using the same procedure as Baldwin, on data relative to the years 1995-'96, however, Nillson (2000) found some unused trade potential between the candidate and the EU countries even if, compared to Baldwin's, the gap between potential and actual trade appears greatly reduced (just 1.1 on average), and several EU countries (except Austria, Portugal, France, Ireland, Spain and the UK) export more to the candidate countries than the gravity model would predict. Also the average ratio relative to

2002) use panel analysis, while Gros and Gonciarz (1996) use both panel analysis and an out-of-sample method. 
the exports to the EU is 0.9 (exceeded export potential) and only for Cyprus, the Czech and the Slovak Republics it is above one.

Turning to the literature on MED, the few studies available invariably suggest that both MED trade with most non-MED countries and intra-MED trade appear low in relation to what would be predicted on the basis of a gravity model. Al-Atrash and Yousef (2000) ${ }^{7}$ find that Mashreq countries exhibit higher levels of integration both within the area and with the rest of the world compared to Maghreb and Gulf countries. EU, Gulf Country Cooperation (GCC) and Arab Maghreb Union (AMU) trading arrangements have not promoted greater integration among member countries. EU trading arrangements even decreased trade.

These results are confirmed by two similar studies. One carried out by IMF (2002), where trade potential of MED, Asia, Africa Sub-Saharan, South America and Central America are compared ${ }^{8}$ and the MED region is found to exhibit the highest degree of under-trading, after South East Asian countries which, however, have a high level of trade in services, which is not included in the gravity estimates. A second more recent study by Miniesy et al. (2004) also finds that the MED region is an "underachiever", especially when trade with the EU and with Eastern Europe is considered. MED trade with the EU was much more developed back in the '70s and '80s up to 1984, while they have cumulated a wide and increasing gap with respect to their potential in the following period. Intra-regional integration is also very poor: the Arab common market, the Gulf Cooperation Council and the three dummy variables for sub-regional trading arrangements within MENA have virtually no effect on the parameters and have a negative and significant coefficient. There are strong "underachievers" in intra-MENA trade like Algeria, Egypt, Kuwait, Qatar, Sudan, Syria, all oil exporting countries, while Jordan, Morocco, Oman, the UAE, Turkey are overachievers.

6 For a survey of the literature on gravity models see Greenaway and Milner (2002).

${ }^{7}$ They apply cross-section maximum likelihood Tobit estimates of bilateral trade between 18 Middle East and North African countries (MENA) and 43 other countries (over 90\% of total MENA trade) using 1995-1997 average data for trade (IMF-DOTS), total GDP and per capita GDP (World Economic Outlook), free trade agreements (ASEAN, EU, the GCC, the AMU), common border, common language, openness and a set of dummies for groups of MENA countries.

8 This study calculates the potential of MENA, Asia, Sub-Saharan Africa, South America and Central America using the parameter estimates from the pooled gravity model of world trade averaged for 1995-99. 
Some recent studies (Mathyas, 1997; and Egger, 2000; 2002) cast three main doubts on the results of the aforementioned literature: 1. most of these results are based on cross-section gravity models which are mis-specified, because they do not take account of exporter and importer effects, while only few authors make use of panel econometrics; 2. authors using panel analysis to compute potential trade adopt a random effect model which may be affected by the problem of correlation between the explanatory variables and the unobserved time invariant effects; 3. most analyses obtain information on trade potentials using the 'in-sample' prediction approach; that is, the residuals of the estimated equation are interpreted as the difference between potential and actual bilateral trade relations, but this is in contrast with the fact that, in the case of proper specification, the estimators are consistent and efficient and therefore should exhibit white-noise residuals, rather than identifying large systematic differences between observed and in-sample predicted values among country groups.

\section{The gravity equation framework}

\subsection{Specification}

In what follows, we estimate the parameters of a gravity model of intra-EU trade ${ }^{9}$ and then plug them into equations of trade between eleven $\mathrm{MED}^{10}$ and ten CEECs, respectively, and their main European trade partners (Italy, Germany, France, UK, and Spain) to calculate potential trade relative to the period 1995-'02. This potential or "normal" trade is then compared to actual trade volumes to assess the dimension of trade potential not exploited in the short run. The period considered includes the years of the output recovery after the transitional shock, before EU accession.

The gravity model is particularly suited for this aim as it provides a sort of "natural benchmark" taking into account both trade enhancing, such as market size (population) and factor endowment (per capita GDP), and trade resistance factors, such as distance. The use of panel data allows us to exploit the

9 The analysis includes 13 EU members, since data for Belgium and Luxembourg is missing for some years.

10 In the Eurostat definition, MED includes 12 countries of the Euro-Mediterranean Partnership: Algeria, Cyprus, Egypt, Jordan, Israel, Lebanon, Malta, Morocco, Syria, Tunisia, Turkey, Palestina and Gaza which is represented by the Palestinian Authority. Libya has the status of observer within the Euro-Mediterranean Partnership. In the empirical analysis, due to the lack of data, we do not include Palestina and Gaza. As far as ex-COMECON 
additional information that the data may convey introducing time invariant parameters and dummy coefficients able to capture country specific features, including historical and cultural linkages (gravity model with fixed effects).

We prefer the following specification to the many alternatives available in the literature. Data sources are given in Table A1 in the Appendix.

$$
\begin{aligned}
X_{i j t}= & \alpha_{i}+\beta_{1} P_{i t}+\beta_{2} G D P P C_{i t}+\beta_{3} P O P_{j t}+\beta_{4} G D P P C_{j t}+\beta_{5} D_{i j} \\
& +\beta_{6} C L B_{i j}+\beta_{7} C L_{i j}+\varepsilon_{i j t}
\end{aligned}
$$

where: $i$ are the countries of origin, $j$ are the destination countries and $t=1995-2002$ is the period under examination; $X_{i j}$ are exports of country $i$ to country $j$ in real terms; $\alpha_{b}$ is the bilateral constant; $P O P_{i t}$ and $P O P_{j t}$ are the populations at time $t$ of country $i$ and $j$ respectively; $G D P P C_{i t}$ and $G D P P C_{j t}$ are per capita GDP of country $i$ and $j$ at time $t$ in real terms ${ }^{11}$; $D_{i j}$ is the geographical distance in Km between the capital city of country $i$ and of country $j$; $C L B$ is a dummy equal to one, if the two countries share a common land border and/or have ex-colony links, and zero otherwise. $C L$ is a dummy taking a value of one if the trade partners speak the same language, and zero otherwise; finally, $\varepsilon_{i j t} \sim \operatorname{IID}\left(0, \sigma_{\varepsilon}^{2}\right)$. Except for the dummies, all the variables are in natural logarithms and, therefore, the estimated parameters can be interpreted as elasticities.

The factors which are expected to affect positively bilateral exports are:

a) the importer demand and exporter supply, as proxied by their population $(P O P)$ and per capita GDP (GDPPC), respectively. A higher per capita income - a proxy of the economic development means a higher import demand and export supply. Trade grows more than proportionally as the economy gets richer: in fact, demand for variety grows with income and leads to a higher share of intraindustry trade in similar goods, since scale economies favour specialisation in differentiated goods (Helpmann and Krugman, 1985). The effect of population is more ambiguous: in fact, on the one hand, a

countries are concerned, this study considers Poland, Hungary, Czech Republic, Slovak Republic, Slovenia, Estonia, Lithuania, Latvia, Bulgaria and Romania.

11 The preferred specification produced the lowest value of the variance inflationary test (VIF) for multicollinearity among a number of alternative cross-section specifications. Total GDP was also used instead of population as a measure of the mass of the partners for robustness checks. Total income variables and population have not been used together because they would cause multicollinearity. By applying this specification, we expect the coefficients of population variables to be positive, as they catch the effects usually caught by absolute GDP. For robustness check, the estimates of trade potential were computed using different specifications. The main results did not change. 
larger population means a large domestic market, a higher degree of self-sufficiency and less need to trade. At the same time, however, a large population entails also a deeper division of labour and scale economies in production, which are generally associated with a larger need for trading. Therefore, the effects of this variable are ambivalent.

b) dummies such as sharing a land or a sea border, ex-colony links, common language capture the geographical closeness, the better information, the lower cultural differences, the lower "home bias" and search and communication costs associated with proximity (familiarity with custom regime, institutions, legal systems).

Conversely, distance is expected to affect negatively bilateral exports. Distance can be measured as geographical remoteness, but also as the surface of host markets, the level of trade costs, the presence of a "home bias" effect and of time and search costs. This variable raises various problems. First, the measurement of distance itself is controversial. If geographical distance is adopted, one should decide whether rail, road or sea distance is the most relevant proxy. Like in several previous studies, this research relies on straight-line distances between capital cities. Such measure may be criticised because it does not take into account the level of development of infrastructures, but it has the advantage of being a transparent and comparable with previous studies. Second, the transformation of the variable may affect the results. The distance can be inserted in levels or transformed in logarithms. We prefer the $\log$ transformation because it reduces the variability of the regressor and the probability to find the coefficient significant when it is not. In turn, this choice provides an indirect test of the overall reliability of the gravity equation, which importantly depends on the distance variable. A third problem regards the sign of the variable. If distance is correlated with differences in comparative advantages, it is not clear which sign should be expected: an increase in the distance variable might increase, not diminish trade. However, as discussed in more detail below, a fixed-effect estimate would bypass this problem, since the distance variable is dropped and its effect is incorporated in the bilateral constant terms. 


\subsection{Panel estimators}

Table 2 reports the results of estimates of different panel models, namely the between effect (BE), the fixed effect (FE) and the random effect (RE) models ${ }^{12}$. Column (1), reports the coefficients of the BE model, which can be thought of as an OLS estimate of cross-section equations of average data relative to the years 1995-'02. The Huber/White/sandwich estimator of variance is used to correct for heteroskedasticity.

\section{[Table 1 about here]}

Column (2), reports the results of a FE, which is equivalent to a least square dummy variable (LSDV) model. In both cases, it is assumed that the error term, $v_{i i t}$, has a complex structure, since it includes a component, $\varepsilon_{i i t}$, which is white noise and a component $v_{i i t}$, which is dependent on unobserved bilateral country-level effects: $v_{i i t}=v_{i}+\varepsilon_{i j t}$, where only $\varepsilon_{i j t} \sim \operatorname{IID}\left(0, \sigma_{\varepsilon}^{2}\right)$.

Equation (1) takes the following form:

$$
X_{i j t}=Z_{i j} \beta+v_{i j t}
$$

where $\beta$ represents the vector of coefficients and $\mathrm{Z}$ the matrix of independent variables as defined in (1). The aim of the FE and of the LSDV is to cancel out the time-invariant effects. While the LSDV obtains this result by including different intercepts for each yearly bilateral trade relation, the FE, instead, takes the distance of every variable from its specific mean for every bilateral trade relation:

$$
\left(X_{i j t}-\bar{X}_{i j}\right)=\left(Z_{i j t}-\bar{Z}_{i j}\right) \beta+\left(\varepsilon_{i j t}-\bar{\varepsilon}_{i j}\right)
$$

This model is sometimes called a within group estimator since it uses only the variation within a set of observations representing specific bilateral trade relations. The unwanted consequence of the FE

12 One of the problems with the FE and the RE models is that they do not allow controlling for the possible autocorrelation of residuals. To check for this we also estimated the FE and the RE with an AR(1) disturbance. The results, not reported here for reasons of space, are very similar to the one shown in the table and are available on request. 
model is that all the time-invariant terms, including the dummy for common land border, common language and distance, are dropped and caught by the bilateral constant term ${ }^{13}$.

Finally, column (3) reports estimates of a RE model of this type:

$$
\left(X_{i j t}-\vartheta \bar{X}_{i j}\right)=(1-\vartheta) \alpha+\left(Z_{i j t}-\vartheta \bar{Z}_{i j}\right) \beta+\left\{(1-\vartheta) \nu_{i j}+\left(\varepsilon_{i j t}-\vartheta \bar{\varepsilon}_{i j}\right)\right\}
$$

This model differs from the FE model in as much as it assumes that the error term is correlated with random, not with fixed effects. In other words, the bias would be due to time-varying factors, which are omitted in the estimate of a normal cross-section estimate.

\subsection{Results}

As the literature on this topic surveyed in section 2 demonstrates, the between estimator has to be discarded immediately, since it does not take into account time-varying factors (for instance, by way of year dummy variables) ${ }^{14}$. This leaves the choice between the FE and the RE models. As shown in Table 1, a Hausman test rejects the hypothesis that the coefficients of the FE model in columns (2) and the RE model in column (3) are equal, which suggests relying on the more consistent FE estimates. In fact, the RE estimates are more efficient than the FE estimates, but they are inconsistent.

On the other hand, though, the FE model is a within estimator and, therefore, does not control for time varying factors. Moreover, it does not explicitly provide estimates of either country effects or of other time-invariant factors, such as distance, common land border or common language. They are fixed effects and are therefore removed in estimates at the difference.

To overcome these shortcomings of the FE model, and taking into account Màtyàs (1997) intuition that both time varying and time invariant effects should be taken into account in the gravity model, the FE and the RE models have been estimated also adding to the general specification a set of dummy variables for the years and one for the exporting and for the importing country. The columns (4) and (5) report the results.

13 The estimator removes the fixed effects by subtracting the time average for each variable for each country and then estimating by ordinary least square the coefficients of these transformed variables.

${ }^{14}$ The estimates are given here as a term of reference to compare this results with the previous ones. 
All the test statistics support the specification in model (5), namely a RE model with exporting and importing countries' and years' dummies. Again, the Breusch and Pagan Lagrange Multiplier test rejects the hypothesis of absence of random effects. However, this time, the Hausman test cannot reject the null hypothesis that the coefficients in column (5) are not statistically different from those in column (4) ${ }^{15}$. Inspection of the $\mathrm{R}^{2}$ also suggests this conclusion, with the $\mathrm{R}^{2}$-within of the $\mathrm{RE}$ model tending to that of the FE model; in addition, the overall $\mathrm{R}^{2}$ increases. Therefore, the tests concurrently support the view that the RE can be safely chosen instead of the FE model. An advantage of model (5) is that it may control for the presence of country (fixed) effects, like a FEM, through the inclusion of country dummies, maintaining the advantages of a REM, namely the higher degree of efficiency and estimated coefficients of the variables CL, CLB and distance. In other words, the model in column (5) has consistent coefficients like that in column (4), while being more efficient.

The biggest difference when comparing the models (4) and (5) comes from the coefficient of the population variables. In particular, the FE estimate is non significant. Most likely, this can be attributed to the role of the time invariant factors. Removing such factors might make the population variable statistically not significant.

In the preferred specification, all the variables have the expected sign and are highly significant. The explanatory power of the model is also high. The statistical significance of distance in explaining the trade intensity of EU countries suggests that transport costs still have an important impact on the export performance. The estimated parameter for distance is stable across different specification and is in line with that typically found in earlier studies (- 0.7).

Also the coefficients are reasonable. Similar to previous studies, the coefficient for the per capita GDP of the exporting country is lower than that of the importing country. This is to be expected, considering that exports are more related to the income level of the importing, rather than of the exporting country. The coefficient of the per capita GDP of the importing country is slightly greater than 1, which is what one would expect if the propensity to import from EU countries was constant over time and the share of EU over total imports was increasing.

15 This result is partly due to the similarity of the coefficients for the year dummies, but also mirrors the tendency of the coefficients of the REM to become closer to those of the FEM, when including dummies for exporting and importing countries. These dummies seem to be able to clean the estimates of most of the fixed effects. 


\section{Estimates of trade potential}

As already noted, the next step consists of applying the estimated coefficients of the gravity equation in column $(5)^{16}$, relative to intra-UE trade, to the same specification for EU-MED (CEECs) trade $^{17}$. These parameters are used as a "benchmark" to estimate the potential integration that MEDs might obtain if the elasticities of trade determinants were the same as those observed in the case of intraEU trade. These trade volumes are considered "normal” flows to which actual flow are to be compared. The same procedure has been applied also to EU-CEE trade. This approach ${ }^{18}$ provides a test to compare the different speeds of the integration process for individual countries in each area and the relative success of the EAs versus the MAAs.

A further test consists of measuring the influence of changes in the explanatory variables on bilateral trade flow predictions. The focus is on predicted per capita GDP growth, assuming constant population as well as the other regressors.

To put our discussion about the trade potential into context, we now turn to sketching out the recent evolution of EU-MED and EU-CEE trade patterns.

\subsection{The recent evolution of trade patterns}

Over the years of the Barcelona partnership, the participation of the south Mediterranean countries to international trade has certainly increased. The annual growth rate has escalated from 4.9 to $6.1 \%$, but it is still lower than that of other less developed countries (6.4\%) (IMF, 2004).

\footnotetext{
${ }^{16}$ The same calculations have been implemented using the coefficients of the FE model in column (2) and in column (4). The results, which are not reported for space limitation, but are available on request, are very similar to those reported here: they slightly differ only in terms of level, but not in terms of trends and ranking of the countries level of integration.

17 It is useful to remark that a shared view in the literature is that, no matter which methodology is adopted, while gravity models have strong power in explaining trade patterns between countries, they are less reliable as an instrument to obtain punctual estimates of the trade level, because of the sensitivity of the estimated coefficients to valuation errors. Most of all, the estimation accuracy of the constant term can have a strong influence on the predicted level of trade flows. Therefore, the prediction accuracy for trade flows in absolute terms is rather low and we should take the following calculation as an indication of the presence of negative or positive gaps of certain intensity but not as a precise measure of them.
} 
According to the estimates of the World trade Organisation relative to 2003, the share of the MED on world merchandise exports is still negligible, at around $2.3 \%$, increasing by only fifteen percent, from the $2.0 \%$ in 1990 . Two thirds of it comes from Turkey, Israel and Algeria. The import share increased by the same amount reaching around 2.8\% in 2003 from $2.5 \%$ in 1990 . The progress is slow if compared to that achieved by the new EU member states of CEE, whose share in world trade has increased by more than one third, from 1.7 in 1995 to $2.8 \%$ in 2003.

Although MED economies are a natural outlet for European trade and capital flows, the current trade with the EU is quite static and asymmetric. They keep today the same share of trade as in the early nineties, about $8 \%$ of total extra-EU trade (around 9\% for exports and 7\% for imports). Conversely, the economies of Eastern Europe have increased the corresponding shares from 7.5 to $12 \%$ circa over the same period. The EU accounts for about 45\% of total MED foreign trade (for the Maghreb area the corresponding figure is 70\% for exports and 60\% for imports) (Eurostat, 2004).

Another feature of MED trade relationships is the high level of concentration on both sides. The countries with higher trade intensity are Malta, Turkey and the Maghreb area ${ }^{19}$. Among EU exporters to MED the most important trade partners, namely France, Germany, Italy, Spain and the UK, together represent more than $70 \%$ of total EU-MED exports and imports thanks to historical and geographical links, such as, for some of them, the access to the Mediterranean Sea.

Also the growth of trade volumes is distributed asymmetrically across countries and shows large differences: during the period 1996-'02, for instance, EU exports scored a high increase in Turkey (81\%), and Algeria (71\%), but only a small one in Lebanon (20\%). The increase in EU imports was in general much lower and took place mostly with Turkey (+138\%). EU imports from Cyprus have even decreased (Eurostat, 2003). Among EU partners, Spain is the one which has benefited the most from trade intensification with an increase in exports equal to $92 \%$ (it was $60 \%$ for France and UK, $46 \%$ for Italy and $42 \%$ for Germany). France, Germany and Italy have increased their imports from the MED economies by 12\% and Spain by 7\%. Overall, MED exports to the EU have increased from 1995 to

18 Namely, the projection of trade relations for groups of countries different with respect to those for which the parameters have been estimated.

19 This study considers the Maghreb countries of Morocco, Algeria and Tunisia (but not of Libya and Mauritania) and the Mashrek countries of Lebanon, Syria, Jordan and Egypt. 
2002 by a factor of around 1.4, a much slower rate than other regions, most notably the CEECs, whose exports to the EU grew by a factor of 5 and more during the same period.

\subsection{Estimates of the trade potential}

The Figures 1 through 10 depict the trends in the trade ratio of potential and actual trade between each of five EU main trade partners (France, Germany, Italy, Spain and UK) and each country in the two areas (MEDs and CEECs) over the period 1995-02. A ratio of one suggests that potential trade equals actual trade. The higher is the ratio, the higher is the gap that has to be filled and therefore the possibility to create new trade. A decreasing (increasing) trend of this ratio over time suggests that trade is increasing (decreasing) and tends to approach its potential level.

\section{[Figures 1-10 about here]}

The ratio between potential and real trade with the MED countries generally shows a constant or, sometimes, an increasing trend. The main exceptions are Tunisia and Turkey (where it is weakly decreasing). This suggests that actual exports between each EU partner and the MED economies has further increased the distance with respect to the "normal" level that they might have reached given the economic, cultural and geographic conditions. The trade potential between EU and MED area is far from being exploited in 2002: the ratio is much higher than 1, ranging between a minimum of around 3.5 and a maximum of 5 for both exports and imports. In other words, the actual volume of trade is only from 20 to less than 30 percent of the potential level.

Conversely, the CEECs show a trend marked by a large decline. Not only they start from a ratio much lower than the MED economies (around 2), they also further close the gap. This is especially the case of countries starting from the worst positions, such as the Baltic Republics and Bulgaria, which show the most dynamic trend. The trade potential between EU and CEECs is close to be exploited in 2002, with a ratio ranging between 2 and 2.6

The projected/actual ratio of imports systematically exceeds that of exports. This result is consistent with the aforementioned evidence of EU trade surpluses with the CEE and MED areas, which are partly due to the low growth rate of EU members. It indicates that there is wide scope for an increase in imports more than in exports if the EU economies started a new era of economic growth. Moreover, it 
might also suggest that the MED still face many barriers to entry in EU markets, or, in other words, that the CEECs have not benefited of a total and preferential opening for their exports to the EU within the EAs.

Consider now the trade relations of individual EU partners with MED countries, first, and with CEE countries, then. France is less distant from its potential with Algeria, Malta, Morocco and Tunisia than with Mashrek countries. Germany has developed trade relations especially with Turkey. Spanish trade is less far from its potential with Tunisia, Turkey and Morocco. The UK exploits its trade potential more intensely with Israel, Malta, Cyprus and Turkey. Finally, compared to the other four partners, Italy has a trade structure spread more evenly across all MED economies. Generally speaking, all the MED countries are in a similar position, although Malta, Israel, Tunisia, and Algeria show a greater degree of integration in both imports and exports (ratio around 4). The underachievement with respect to the model predictions is higher with Cyprus, Jordan and Lebanon, especially as far as imports are concerned.

Trade relations with CEECs are by far more developed. French trade with Slovenia, Poland and Romania is closer to its potential than that with other countries, especially the Baltic Republics. Nonetheless, a clear process of convergence seems to be in place. Italy's case is similar to that of France. Germany is slightly different, as it shows a greater degree of integration with Central European countries, especially the Czech Republic, Hungary, Poland and Slovenia. With some of these countries, the ratio approaches 2 in recent years. For Spain, trade seems to be closer to exhaustion especially with Hungary, the Czech Republic and Slovenia (for exports). The ratio is generally higher for the UK, especially with Bulgaria and Estonia.

\subsection{Forecasting trade growth}

Table 2 presents projections of the export and import annual growth rates. These figures have been obtained by applying the annual growth rates of per capita GDP, as foreseen by the World Bank for the period 2003-2007, to the coefficients of our gravity equation (section 3), and assuming zero population 
growth ${ }^{20}$. Studying the impact of other factors, which might also affect the evolution of trade flows (e.g. reduction of trade costs in the MEDs via tariffs removal or infrastructures investments), cannot be dealt with within the gravity framework and is, therefore, beyond the scope of this paper.

\section{[Tab. 2 about here]}

A common feature of the table is that EU exports grow faster than EU imports for both groups of partners, which depends essentially on the higher predicted growth rate of partner countries and the higher coefficient of $G D P_{j}$. However, important differences exist between the two areas. In particular, among the CEECs, as a consequence of their higher per capita GDP growth rates, Bulgaria, Romania and the Baltic States appear to have a very fast growing trade with growth rates for EU exports between 6 (Romania) and almost 10 percent (Bulgaria) and growth rates for EU imports between 4.5 (Romania) and 7 percent (Bulgaria). However, also the remaining CEECs show a very good performance with growth rates of EU exports which are all above 5\%, and growth rates of EU imports above 4.5\%, with the exception of the Czech Republic (average rates of 2.7 and 3.3 for EU-5 exports and imports respectively) and Poland (average rates of 4.5 and 4.3 ).

Among MED countries and with the exception of Malta ${ }^{21}$, only Tunisia, Turkey and Algeria's trade grows at a rate of around 5\%. The remaining countries have much lower rates, e.g. Lebanon (average rates of 1.5 and of 2.5) and Israel (between 2 and 2.7 respectively).

Given these projections, the perspectives of convergence of actual towards potential trade are different across and within the two groups of countries. Table 3 reports the number of years, which are necessary according to the previous calculations for the actual to reach potential levels of trade. The figures have been obtained by dividing the ratio in 2002 (multiplied by 100) for the projected export and import annual growth rates reported in Table 2. Inspection of the table suggests that Bulgaria, Romania and the Baltic Republics should be able to converge in a relatively short period of time (between around 24 and 70 years): in fact, they developed trade with the EU later than other CEECs, but have a much higher growth rate in the coming years. Conversely, even the most advanced MED economies (Tunisia,

\footnotetext{
${ }^{20}$ The World Bank projections relative to the growth rate of some countries are unavailable. They have been, therefore, substituted by average growth rates during the decade 1993-'03.

${ }^{21}$ Malta experienced an exceptional growth rate (above 7.7), but is a special case as it is a small countries and has recently joined the EU.
} 
Morocco and Turkey) will reach their potential in not less than 40 years. For many MED countries, especially Israel, Lebanon, Syria, Morocco convergence of actual to potential trade will never be achieved without extraordinary changes in the EU trade policy.

\section{[Table 3 about here]}

\section{Concluding remarks}

The EU is placing remarkable political emphasis on the integration process with the third Mediterranean countries involved in the 1995 Barcelona process (MED12). However, trade integration with the MED countries seems to be still underdeveloped. Conversely, many observers assume that a significant level of trade integration with the new EU members has been already achieved. To contrast the success of EU integration with these two areas, this paper computes the trade potential of a sample of old EU members (Italy, Germany, France, UK, Spain) from 1995 to 2002 using an "out-of-sample” methodology. The coefficients are taken from different panel estimators of the gravity equation relative to intra-EU trade. The chosen specification is a random effect model including controls for exporting countries, importing countries and years. The results, which are remarkably stable across different specifications and estimation methods, suggest the existence of an important unexploited trade potential with both groups of partners, although the ratio of potential to actual trade with the MED countries is much larger and dispersed compared to that with the CEECs and unlike these countries which are rapidly closing the gap, it is on the rise.

While our results converge with previous studies which also found a large "under trading” between EU and MEDs (Rose, 2002; IMF, 2002) it is in contrasts with the existing literature in the case of the CEECs (and in line only with Baldwin, 1994; and 1997). The differences from previous gravity studies depend on the period of analysis, on the estimation method and the procedure used to compute potential trade. Previous research almost universally deployed cross-section and "in sample” methods on early 1990s data, when, as Baldwin (1997) notes, GDP in the CEECs was depressed by the transition phase.

It seems clear that for trade to reach exhaustion it is important to deepen bilateral and multilateral forms of integration via trade promotion measures. Moreover, the results, which show a very large scope 
for trade growth, also suggest that a further adjustment process might take place in the labour market of EU members and of associate countries in the next few years. 


\section{References}

Al-Atrash, H.M., and T. Yousef (2000). Intra-Arab trade: is it Too Little? IMF working papers, 00/10.

Baldwin, R.E. (1994). Towards an Integrated Europe. London: Centre for Economic Policy Research.

Baldwin, R.E. (1997). Comment on Gros and Gonciarz. European Journal of Political Economy 13(1): 187-188.

Brenton, P., and D. Gros (1997). Trade Reorientation and Recovery in Transition Economies. Oxford Review of Economic Policy 13(2): 65-76.

Brenton, P., and F. Di Mauro (1999). The Potential Magnitude and Impact of FDI Flows to CEECs. Journal of Economic Integration 14(1): 59-74.

Buch, C. M., J. Kleinert, and F. Toubal (2004). The Distance Puzzle: On the Interpretation of the Distance Coefficient in Gravity Equations. Economics Letters 83(3): 293-298.

Egger, P. (2000). A Note on the Proper Econometric Specification of the Gravity Equation. Economics Letters 66(1): 25-31.

Egger, P. (2002). An Econometric View on Estimation of Gravity Models and the Calculation of Trade Potential. World Economy 25(2): 297-312.

Eurostat (various years), Statistics in focus, Bruxelles.

European Commission (1997) “Agenda 2000”, Brussels.

Feenstra, R.C., J.R. Markusen, and A.K. Rose (2001). Using the Gravity Equation to Differentiate among Alternative Theories of Trade. Canadian Journal of Economics 34(2): 430-447.

Femise (2002). Report on the Euro-Mediterranean Partnership. Marseille: Femise.

Fontagnè, L., P. Artus, and A. Cartapanis (1999) L'Elargissement de l’Union Europeenne en Europe Centrale: Les Enjeux. Revue Economique 50(6): 1095-99.

Greenaway, D., and C. Milner (2002). Regionalism and Gravity. Scottish Journal of Political Economy 49(5): 574-585.

Gros, D., and Gonciarz A. (1996). A Note on the Trade Potential of Central and Eastern Europe. European Journal of Political Economy 12(4): 709-721.

Hamilton, C.B., and A.L. Winters (1992). Opening Up International Trade with Eastern Europe. Economic Policy 14: 77-116.

Hassan, M.K. (1998). An Empirical Investigation of Economic Cooperation among the OIC Member Countries. ERF working paper 0212.

Helpman, E., and P. Krugman (1985). Market Structure and Foreign Trade. Cambridge Mass: MIT Press.

IMF (various years). World Economic Outlook. Washington: IMF.

Mathyas, L. (1997). Proper Econometric Specification of the Gravity Model. World Economy 20(3): 363-368.

Miniesy, R.S., J.B. Nugent, and T.M. Yousef (2004). Intra-regional trade integration in the Middle East. Past performance and future potential. In Hakimian, H., and J.B. Nugent (eds.) Trade Policy and Economic Integration in the Middle East and North Africa. Economic boundaries in flux. London: Routledge.

Nilsson, L. (2000). Trade integration and the EU economic membership criteria. European Journal of Political Economy 16(4): 807-27.

Rose, A.K. (2002). Estimating Protectionism from the Gravity Model. Mimeo. Washington: IMF. 
Wang, Z., and Winters A.L. (1992). The Trading Potential of Eastern Europe. Journal of Economic Integration 7(2): 113-136. 
Table 1: Gravity model estimates of intra-EU trade (1995-2002)

\begin{tabular}{|c|c|c|c|c|c|}
\hline & $\begin{array}{c}\text { BEM } \\
\text { (1) }\end{array}$ & $\begin{array}{c}\text { FEM } \\
\text { (2) }\end{array}$ & $\begin{array}{c}\text { REM } \\
\text { (3) }\end{array}$ & $\begin{array}{c}\text { FEM } \\
\text { (4) }\end{array}$ & $\begin{array}{c}\text { REM } \\
\text { (5) }\end{array}$ \\
\hline Const & $6.00^{* * *}$ & $-6.75^{* * *}$ & -1.36 & -0.63 & $3.88^{* *}$ \\
\hline Lgdpi & $1.27^{* * *}$ & $0.68^{* * * *}$ & $1.15^{* * *}$ & $0.37^{* * *}$ & $0.53^{* * * *}$ \\
\hline Lgdpj & $0.41^{* * * *}$ & $1.59^{* * * *}$ & $1.10^{* * * *}$ & $1.27^{* * *}$ & $1.06^{* * * *}$ \\
\hline Lpopi & $0.82^{* * *}$ & $2.01^{* * * *}$ & $0.84^{* * *}$ & $2.03^{* * *}$ & $1.01^{* * * *}$ \\
\hline Lpopj & $0.88^{* * *}$ & -0.02 & $0.91^{* * *}$ & 0.00 & $1.04^{* * *}$ \\
\hline Ldist & $-0.78^{* * *}$ & & $-0.64^{* * *}$ & & $-0.61^{* * * *}$ \\
\hline Clg & 0.24 & & 0.26 & & 0.08 \\
\hline $\mathrm{Clb}$ & 0.15 & & 0.17 & & $0.47^{* * *}$ \\
\hline $\mathrm{Sd}\left(\mathrm{u}_{\mathrm{i}}+\mathrm{e}_{\mathrm{i}}\right)$ & 0.56 & & & & \\
\hline $\operatorname{Corr}\left(\mathrm{u}_{\mathrm{i}}, \mathrm{XB}\right)$ & & -0.68 & 0 & -0.69 & 0 \\
\hline$\sigma_{\mathrm{u}}$ & & 1.88 & 0.56 & 1.88 & 0.36 \\
\hline$\sigma_{\mathrm{e}}$ & & 0.13 & 0.13 & 0.13 & 0.13 \\
\hline$\rho\left(\right.$ fraction of $\sigma^{2}$ due to $\left.u_{i}\right)$ & & 1.00 & 0.95 & 1 & 0.89 \\
\hline$F($ all ui $=0$ ) & & $124.0^{* * *}$ & & $50.1^{* * * *}$ & \\
\hline RE of ui & & & Gaussian & & Gaussian \\
\hline$\theta$ & & & 0.91 & & 0.87 \\
\hline $\mathrm{R}^{2}$-within & 0.59 & 0.64 & 0.63 & 0.67 & 0.67 \\
\hline $\mathrm{R}^{2}$-between & 0.89 & 0.31 & 0.87 & 0.30 & 0.95 \\
\hline $\mathrm{R}^{2}$-overall & 0.88 & 0.31 & 0.86 & 0.30 & 0.95 \\
\hline F (all coeffs) & $166.6^{* * *}$ & $414.3^{* * *}$ & $2635^{* * *}$ & $187.7^{* * *}$ & $4752.9^{* * *}$ \\
\hline Hausman test & & \multicolumn{2}{|c|}{$76.9^{* *}$} & \multicolumn{2}{|c|}{4.85} \\
\hline $\begin{array}{l}\text { Breusch and Pagan } \\
\text { Lagrange Multiplier test } \\
\text { for RE }\end{array}$ & & & $2846^{* * *}$ & & $2359.2^{* * *}$ \\
\hline Nobs & 1085 & 1085 & 1085 & 1085 & 1085 \\
\hline N. of groups & 155 & 155 & 155 & 155 & 155 \\
\hline Obs per group & 7 & 7 & 7 & 7 & 7 \\
\hline
\end{tabular}

a) Column (1) reports the coefficients of the between-effect model. The Huber/White/sandwich estimator of variance is used to correct for heteroskedasticity. The columns (2) and (4) report the results of fixed-effect models, of which the latter includes dummies for years. The columns (3) and (5) report estimates of random-effects models, of which the latter includes dummies for years, exporting and importing countries.

b) ${ }^{* * *}$ denotes a $1 \%$ significance level; ${ }^{* *}$ denotes a $5 \%$ significance level and ${ }^{*}$ denotes a $10 \%$ significance level. No stars means not significant.

c) The $\mathrm{R}^{2}$ have a panel meaning and cannot be interpreted exactly like the OLS $\mathrm{R}^{2}$. Two properties of this last are missing in the panel $\mathrm{R}^{2}$. This last does not represent the squared correlation between the fitted and actual values and is not, therefore, equal to the fraction of the variation in the dependent variable explained by the variation of the fitted value. In other words, they do not denote the fraction of variance of the dependent variable explained by the variance of the estimated variable. The $\mathrm{R}^{2}$-within, the $\mathrm{R}^{2}$-between and the $\mathrm{R}^{2}$-overall represent the within, between and overall interpretation of the estimated model.

d) Notice that in the REM the Corr $\left(\mathrm{u}_{\mathrm{i}}, \mathrm{XB}\right)$ is assumed to be zero.

e) The Breusch and Pagan test for random effects is a Lagrange Multiplier test on the $H_{0}: \sigma_{u_{i}}^{2}=0$. Rejecting this hypothesis suggests that the REM model is appropriate.

f) $\mathrm{H}_{0}$ for the Hausman test is that all the common coefficients between the FEM and the REM are not statistically different.

g) $\theta$ represents the estimated value in the following REM: $\left(y_{i t}-\vartheta \bar{y}_{i}\right)=(1-\vartheta) \alpha+\left(x_{i t}-\vartheta \bar{x}_{i}\right) \beta+\left\{(1-\vartheta) v_{i}+\left(\varepsilon_{i t}-\vartheta \bar{\varepsilon}_{i}\right)\right\}$, where $\mathrm{x}_{\mathrm{it}}$ is the matrix of independent variables and vi are the time invariant fixed effects. 
Table 2: Projected export and import annual growth rates (in \%age).

\begin{tabular}{|c|c|c|c|c|c|c|c|c|c|c|c|c|c|}
\hline \multirow[b]{2}{*}{ CEEC } & \multirow{2}{*}{$\begin{array}{l}\text { Projected GDP per capita } \\
\text { annual growth rates } \\
\text { 2003-07 }\end{array}$} & \multicolumn{2}{|c|}{ France } & \multicolumn{2}{|c|}{ Germany } & \multicolumn{2}{|c|}{ Italy } & \multicolumn{2}{|c|}{ Spain } & \multicolumn{2}{|c|}{ UK } & \multicolumn{2}{|c|}{$\mathrm{EU}$} \\
\hline & & $\mathrm{E}^{1}$ & $\mathrm{M}^{2}$ & $\mathrm{E}$ & $\mathrm{M}$ & $\mathrm{E}$ & $\mathrm{M}$ & $\mathrm{E}$ & $\mathrm{M}$ & $\mathrm{E}$ & $\mathrm{M}$ & $\mathrm{E}$ & $\mathrm{M}$ \\
\hline Bulgaria & 8,2 & 9,7 & 6,4 & 9,4 & 5,7 & 9,6 & 6,1 & 10,2 & 7,3 & 10,0 & 7,0 & 9,8 & 6,5 \\
\hline Estonia & 5,8 & 7,2 & 5,1 & 6,8 & 4,5 & 7,0 & 4,9 & 7,6 & 6,0 & 7,5 & 5,7 & 7,2 & 5,2 \\
\hline Hungary $^{3}$ & 3,9 & 5,1 & 4,1 & 4,8 & 3,4 & 5,0 & 3,9 & 5,6 & 5,0 & 5,5 & 4,7 & 5,2 & 4,2 \\
\hline Latvia & 6,8 & 8,2 & 5,6 & 7,9 & 5,0 & 8,1 & 5,4 & 8,7 & 6,6 & 8,5 & 6,3 & 8,3 & 5,8 \\
\hline Lithuania & 6,6 & 8,0 & 5,5 & 7,7 & 4,9 & 7,9 & 5,3 & 8,5 & 6,5 & 8,3 & 6,1 & 8,1 & 5,7 \\
\hline Poland & 3,2 & 4,4 & 3,7 & 4,1 & 3,1 & 4,3 & 3,5 & 4,9 & 4,7 & 4,7 & 4,3 & 4,5 & 3,9 \\
\hline Romania & 5 & 6,3 & 4,7 & 6,0 & 4,0 & 6,2 & 4,5 & 6,8 & 5,6 & 6,6 & 5,3 & 6,4 & 4,8 \\
\hline Slovenia $^{3}$ & 4,1 & 5,4 & 4,2 & 5,0 & 3,6 & 5,2 & 4,0 & 5,8 & 5,1 & 5,7 & 4,8 & 5,4 & 4,3 \\
\hline The Czech Republic ${ }^{3}$ & 2,1 & 3,2 & 3,1 & 2,9 & 2,5 & 3,1 & 2,9 & 3,7 & 4,1 & 3,6 & 3,8 & 3,3 & 3,3 \\
\hline The Slovak Republic & 3,8 & 5,0 & 4,0 & 4,7 & 3,4 & 4,9 & 3,8 & 5,5 & 5,0 & 5,4 & 4,7 & 5,1 & 4,2 \\
\hline \multicolumn{14}{|l|}{ MED-11 } \\
\hline Algeria & 4,1 & 5,4 & 4,2 & 5,0 & 3,6 & 5,2 & 4,0 & 5,8 & 5,1 & 5,7 & 4,8 & 5,4 & 4,3 \\
\hline Cyprus $^{3}$ & 3,3 & 4,5 & 3,8 & 4,2 & 3,1 & 4,4 & 3,6 & 5,0 & 4,7 & 4,8 & 4,4 & 4,6 & 3,9 \\
\hline Jordan & 3 & 4,2 & 3,6 & 3,9 & 3,0 & 4,1 & 3,4 & 4,7 & 4,6 & 4,5 & 4,2 & 4,3 & 3,8 \\
\hline Egypt $^{3}$ & 2,6 & 3,8 & 3,4 & 3,4 & 2,8 & 3,7 & 3,2 & 4,2 & 4,3 & 4,1 & 4,0 & 3,8 & 3,5 \\
\hline Israel & 1 & 2,1 & 2,5 & 1,7 & 1,9 & 2,0 & 2,3 & 2,5 & 3,5 & 2,4 & 3,2 & 2,1 & 2,7 \\
\hline Lebanon & 0,7 & 1,7 & 2,4 & 1,4 & 1,7 & 1,6 & 2,2 & 2,2 & 3,3 & 2,1 & 3,0 & 1,8 & 2,5 \\
\hline Malta $^{3}$ & 6,6 & 8,0 & 5,5 & 7,7 & 4,9 & 7,9 & 5,3 & 8,5 & 6,5 & 8,3 & 6,1 & 8,1 & 5,7 \\
\hline Morocco & 1,5 & 2,6 & 2,8 & 2,3 & 2,2 & 2,5 & 2,6 & 3,1 & 3,8 & 2,9 & 3,4 & 2,7 & 3,0 \\
\hline Syria & 1,5 & 2,6 & 2,8 & 2,3 & 2,2 & 2,5 & 2,6 & 3,1 & 3,8 & 2,9 & 3,4 & 2,7 & 3,0 \\
\hline Tunisia & 4 & 5,2 & 4,1 & 4,9 & 3,5 & 5,1 & 3,9 & 5,7 & 5,1 & 5,6 & 4,8 & 5,3 & 4,3 \\
\hline Turkey & 4,1 & 5,4 & 4,2 & 5,0 & 3,6 & 5,2 & 4,0 & 5,8 & 5,1 & 5,7 & 4,8 & 5,4 & 4,3 \\
\hline
\end{tabular}

Notes: ${ }^{1}$ Projected growth rates of exports; ${ }^{2}$ Projected growth rates of imports; ${ }^{3}$ Based on average incomes growth rates 1993-03, assuming zero population growth.

Source: Own elaboration on World Bank projected annual growth rates of per capita GDP. 
Table 3: Number of years necessary for actual to approach potential trade

\begin{tabular}{|c|c|c|c|c|c|c|c|c|c|c|c|c|}
\hline \multirow[b]{2}{*}{ CEEC } & \multicolumn{2}{|c|}{ France } & \multicolumn{2}{|c|}{ Germany } & \multicolumn{2}{|c|}{ Italy } & \multicolumn{2}{|c|}{ Spain } & \multicolumn{2}{|c|}{ UK } & \multicolumn{2}{|c|}{ EU } \\
\hline & $\mathrm{E}^{1}$ & $\mathrm{M}^{2}$ & E & M & $\mathrm{E}$ & $\mathrm{M}$ & $\mathrm{E}$ & M & E & $\mathrm{M}$ & $\mathrm{E}$ & M \\
\hline Bulgaria & 24 & 38 & 24 & 40 & 23 & 36 & 24 & 33 & 25 & 35 & 24 & 38 \\
\hline Estonia & 33 & 50 & 33 & 52 & 32 & 51 & 33 & 41 & 34 & 40 & 33 & 50 \\
\hline Hungary $^{3}$ & 43 & 55 & 43 & 61 & 43 & 57 & 41 & 46 & 43 & 48 & 43 & 55 \\
\hline Latvia & 29 & 44 & 27 & 46 & 28 & 45 & 28 & 40 & 29 & 35 & 29 & 44 \\
\hline Lithuania & 29 & 43 & 28 & 47 & 29 & 46 & 28 & 37 & 29 & 38 & 29 & 43 \\
\hline Poland & 50 & 62 & 52 & 70 & 50 & 64 & 47 & 51 & 49 & 53 & 50 & 62 \\
\hline Romania & 36 & 49 & 36 & 56 & 34 & 48 & 36 & 43 & 37 & 44 & 36 & 49 \\
\hline Slovenia $^{3}$ & 41 & 54 & 43 & 61 & 41 & 55 & 40 & 48 & 41 & 50 & 41 & 54 \\
\hline The Czech Republic ${ }^{3}$ & 68 & 73 & 72 & 85 & 70 & 76 & 62 & 57 & 66 & 60 & 68 & 73 \\
\hline The Slovak Republic & 46 & 59 & 45 & 63 & 45 & 59 & 42 & 49 & 44 & 52 & 46 & 59 \\
\hline \multicolumn{13}{|l|}{ MED-11 } \\
\hline Algeria & 65 & 88 & 83 & 106 & 70 & 89 & 63 & 68 & 70 & 80 & 65 & 88 \\
\hline Jordan & 87 & 120 & 94 & 148 & 92 & 137 & 85 & 102 & 83 & 99 & 87 & 120 \\
\hline Cyprus $^{3}$ & 78 & 105 & 84 & 130 & 81 & 122 & 74 & 88 & 73 & 83 & 78 & 105 \\
\hline Egypt $^{3}$ & 99 & 121 & 106 & 147 & 102 & 120 & 92 & 92 & 93 & 95 & 99 & 121 \\
\hline Israel & 174 & 150 & 198 & 190 & 181 & 160 & 143 & 107 & 146 & 113 & 174 & 150 \\
\hline Lebanon & 206 & 188 & 251 & 256 & 217 & 202 & 169 & 130 & 181 & 142 & 206 & 188 \\
\hline Malta $^{3}$ & 43 & 69 & 46 & 76 & 43 & 72 & 41 & 62 & 42 & 60 & 43 & 69 \\
\hline Morocco & 135 & 131 & 162 & 177 & 149 & 150 & 116 & 97 & 129 & 109 & 135 & 131 \\
\hline Syria & 148 & 139 & 162 & 168 & 148 & 141 & 130 & 103 & 135 & 115 & 148 & 139 \\
\hline Tunisia & 65 & 87 & 72 & 105 & 67 & 92 & 64 & 74 & 69 & 83 & 65 & 87 \\
\hline Turkey & 67 & 89 & 68 & 99 & 68 & 91 & 62 & 72 & 64 & 74 & 67 & 89 \\
\hline
\end{tabular}

Notes: ${ }^{1}$ Exports; ${ }^{2}$ Imports; ${ }^{3}$ Based on average incomes growth rates 1993-03.

Source: Own elaboration based on Figure 1 through 10 (year 2002) and Table 2. 
Figures 1-10

France-CEECS: Ratio of potential to actual trade (1995-'02)

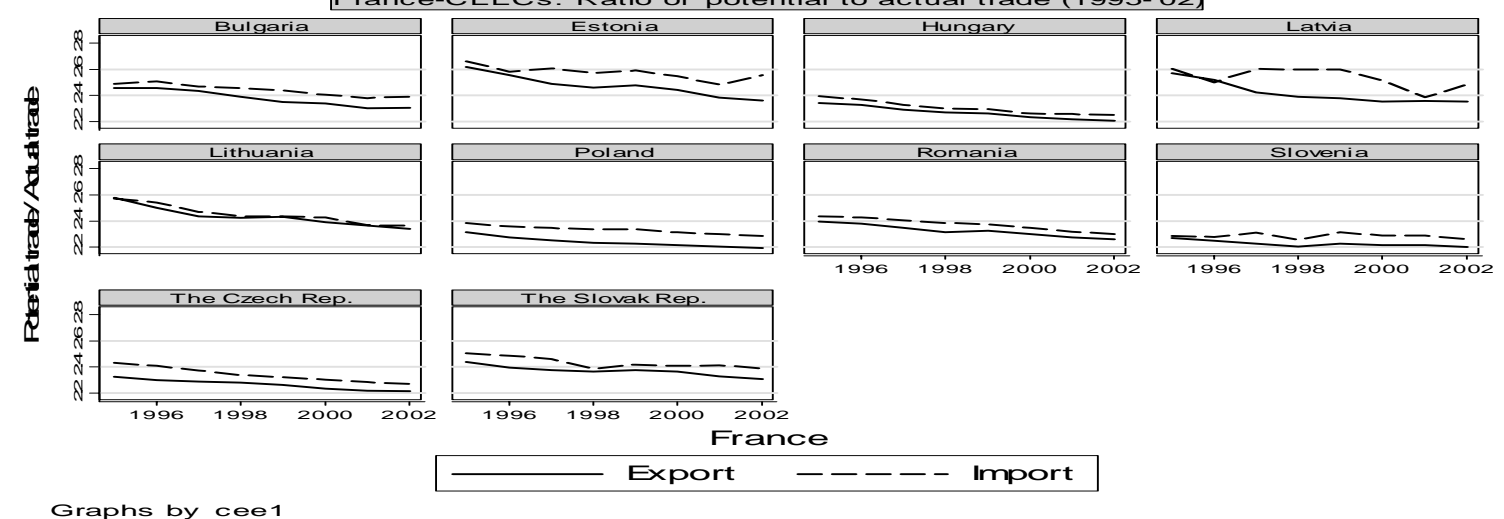

France-MED: Ratio of potential to actual trade (1995-'02)

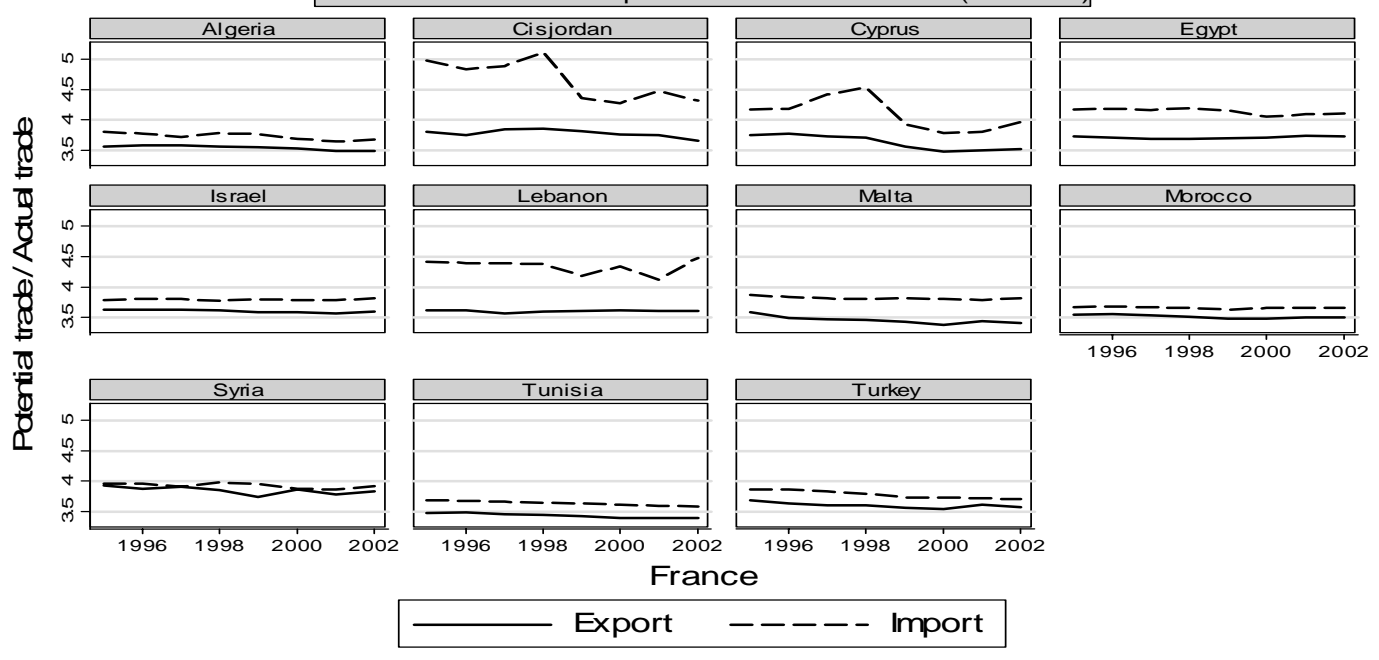

Graphs by med1 


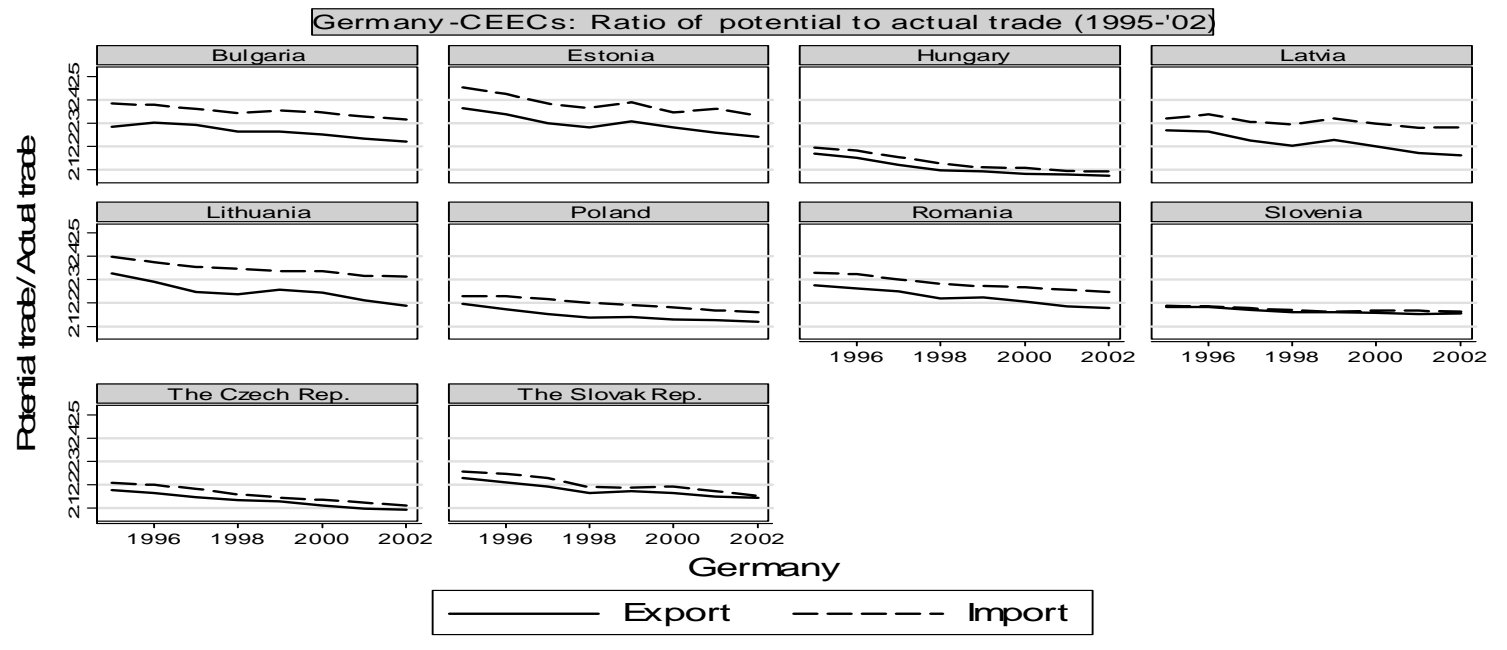

Graphs by cee 1

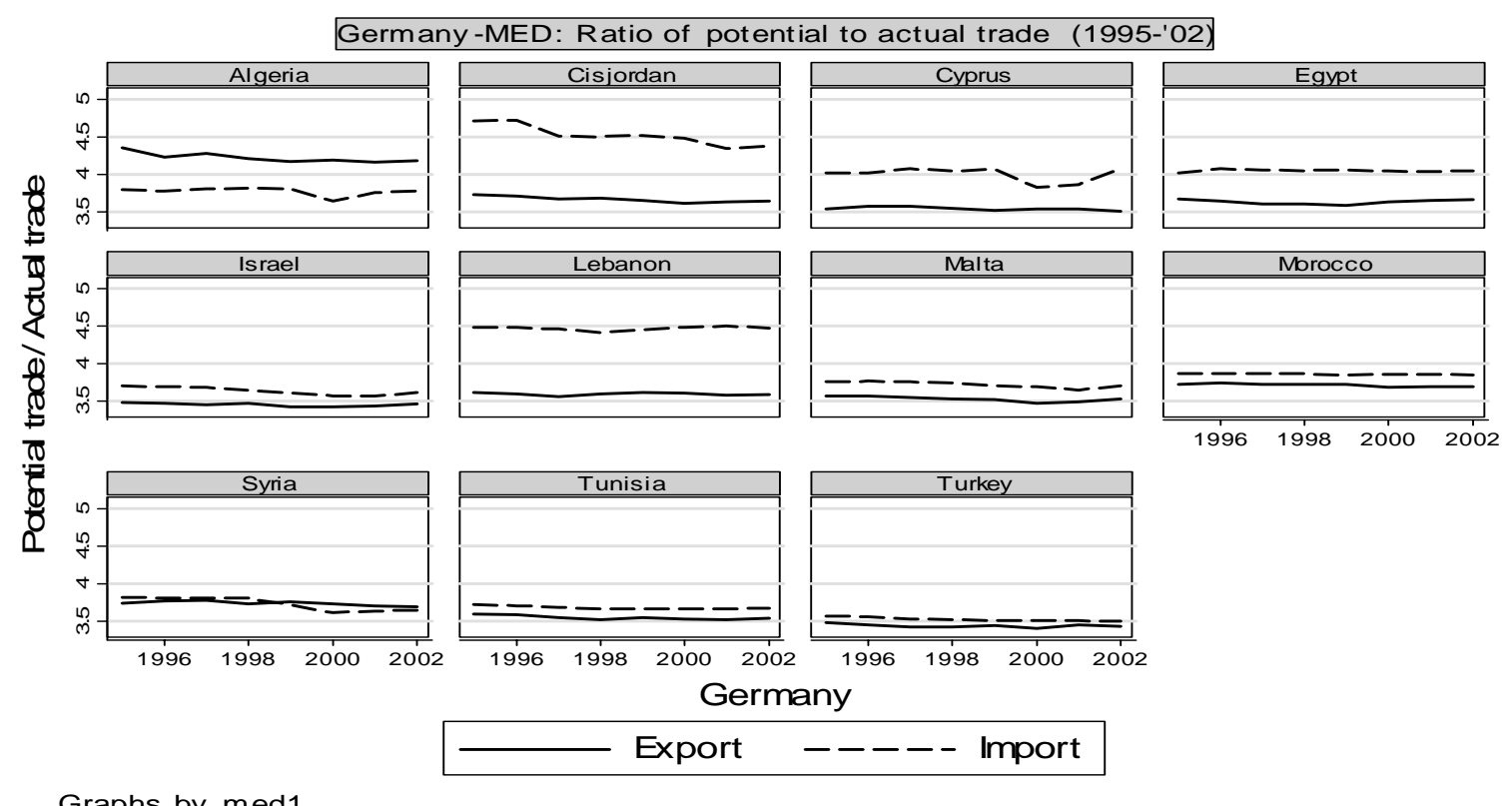

Graphs by med1

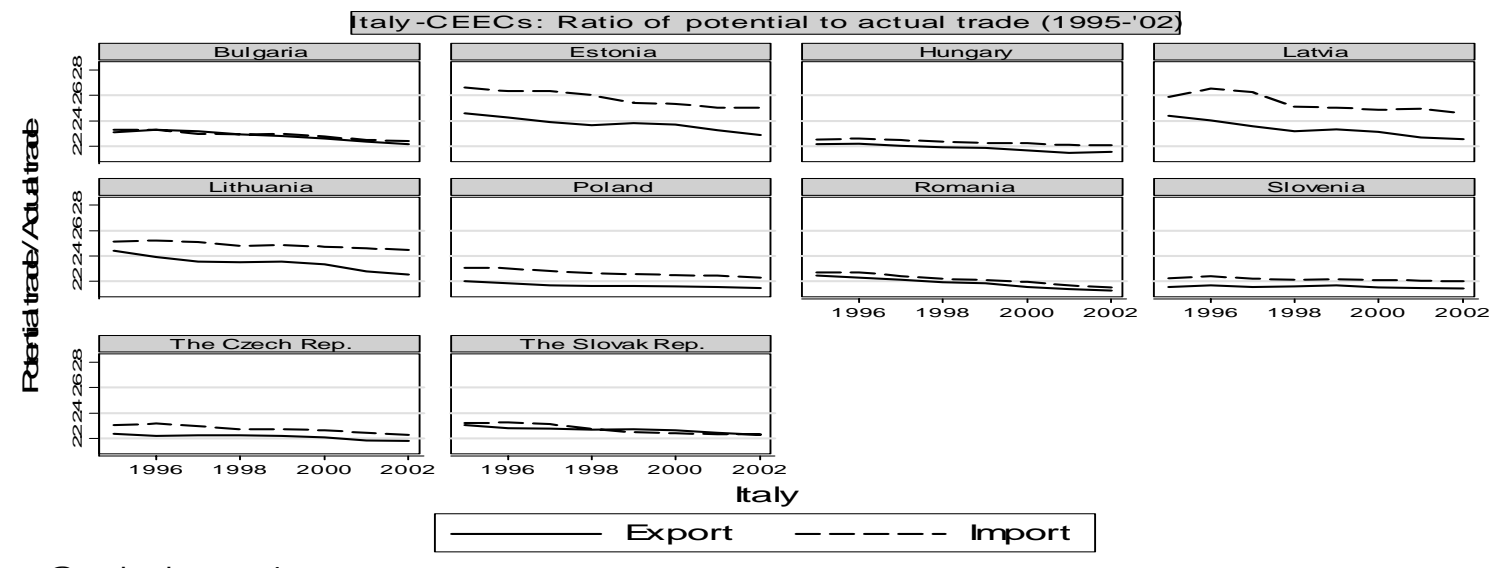

Graphs by cee1 


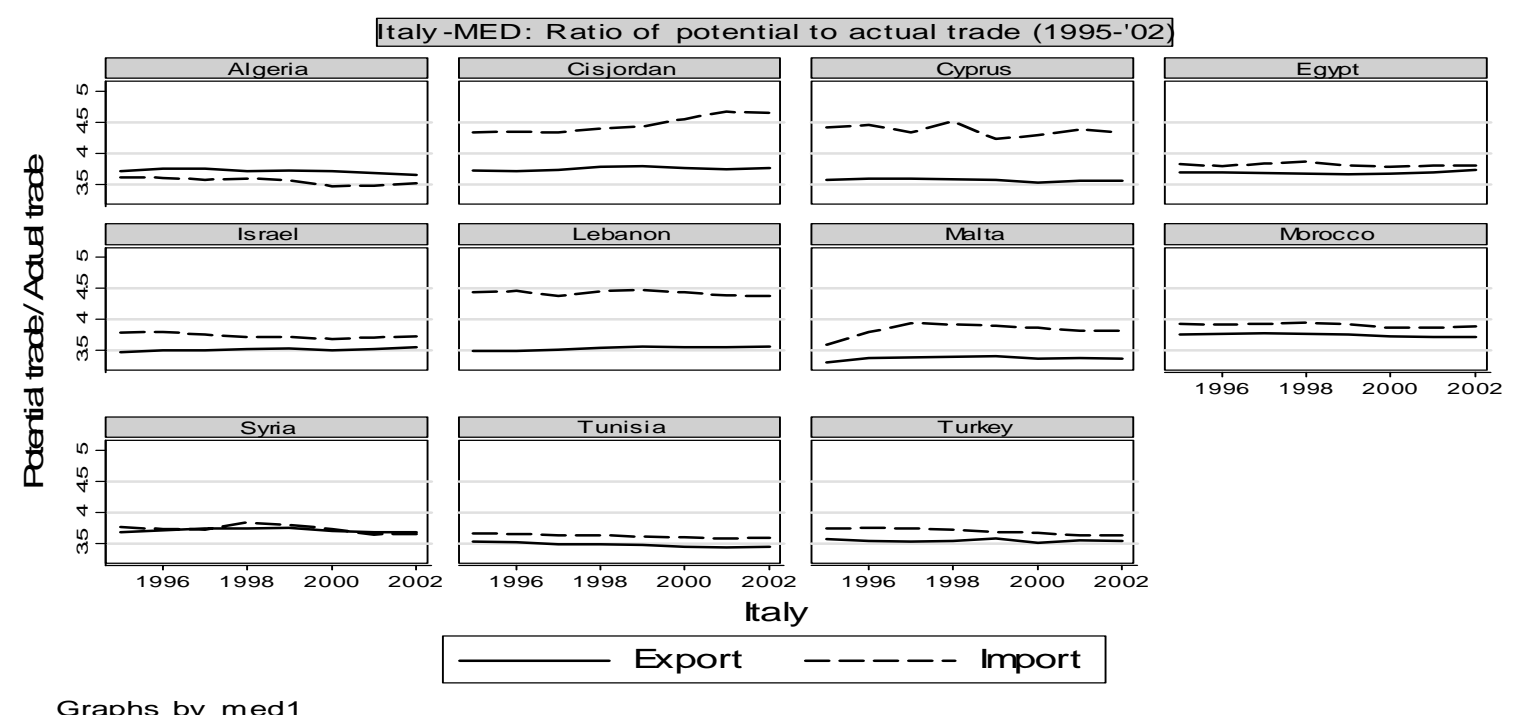

Graphs by med1

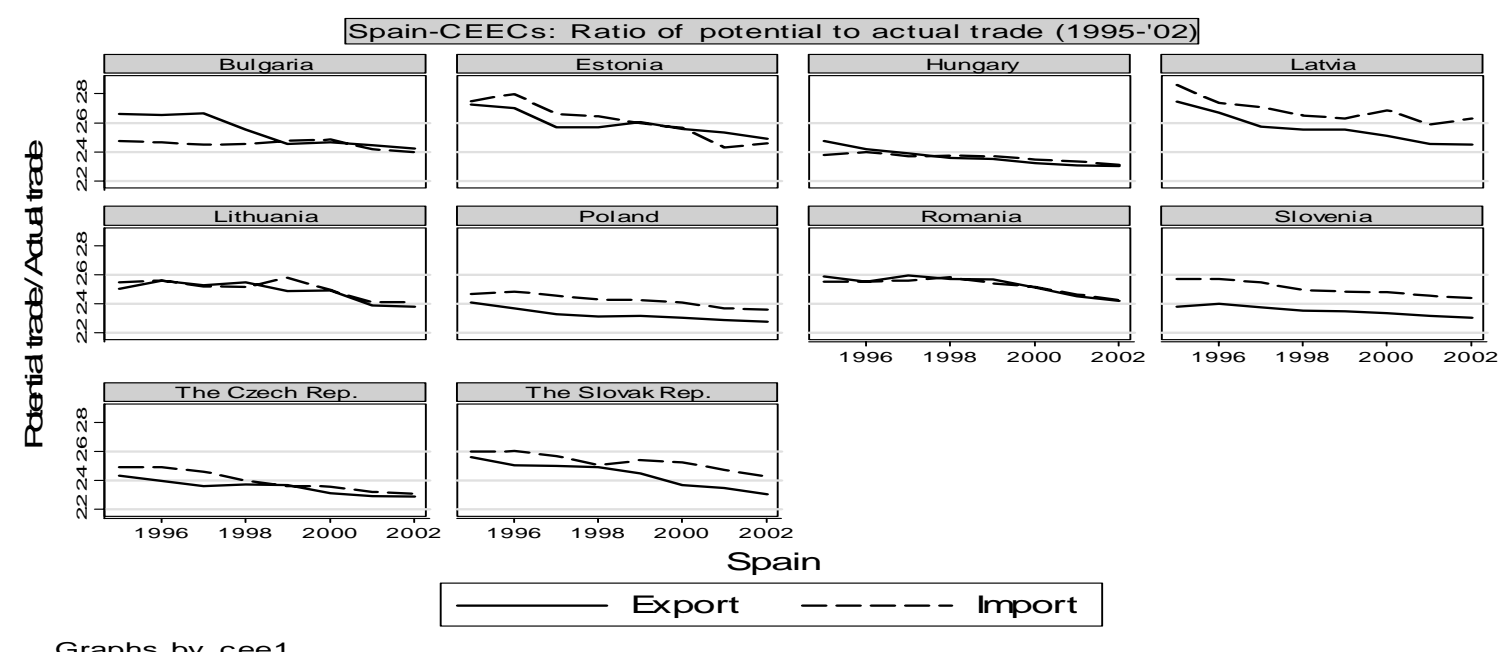

Graphs by cee 1

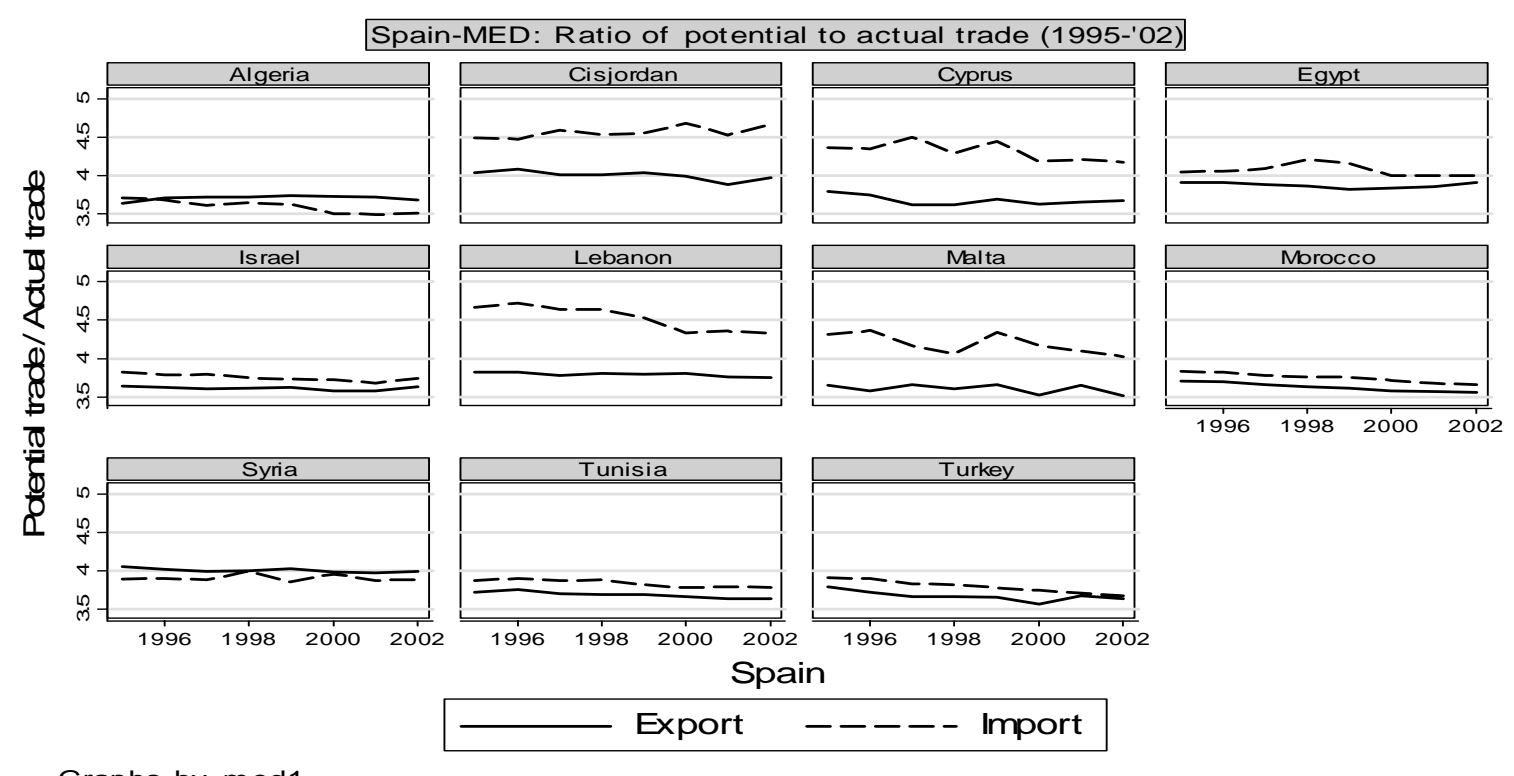

Graphs by med1 


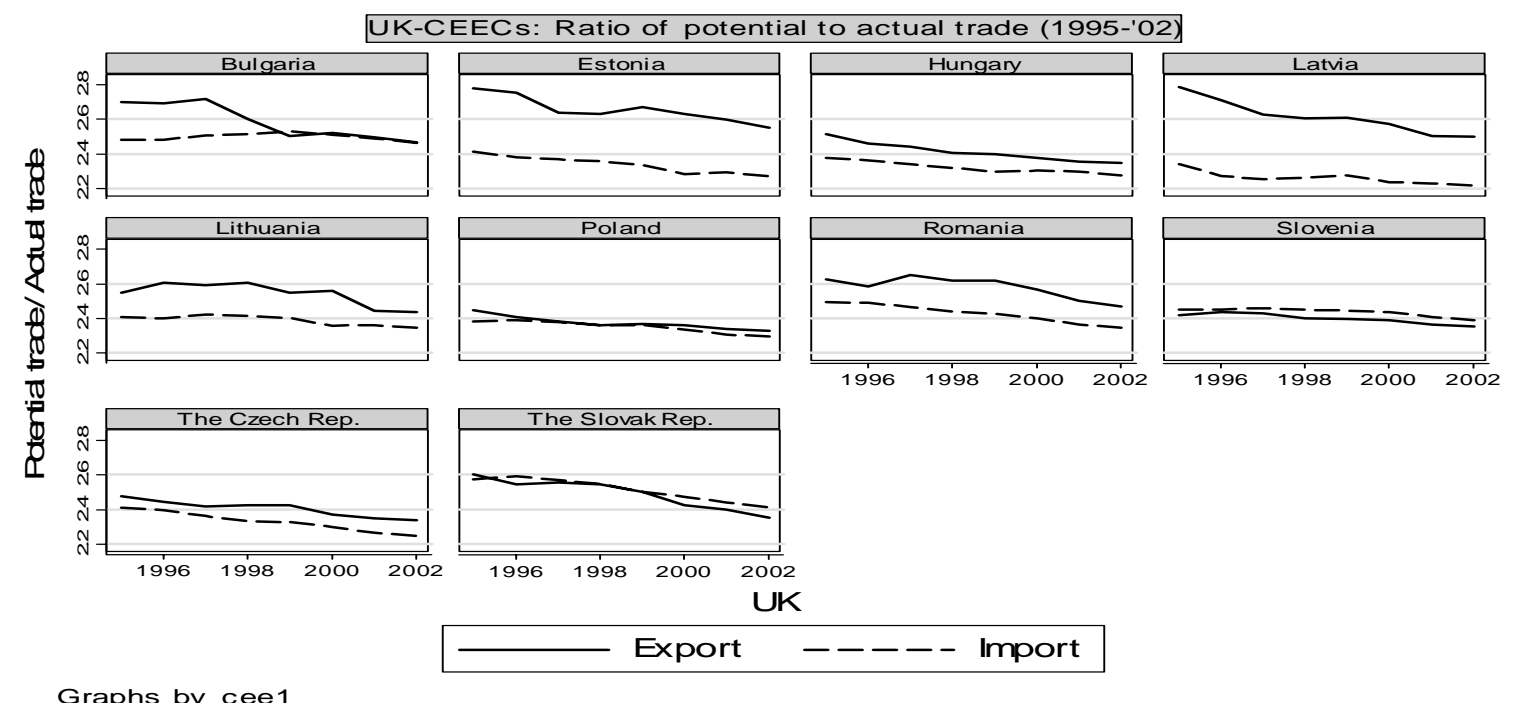

Graphs by cee1

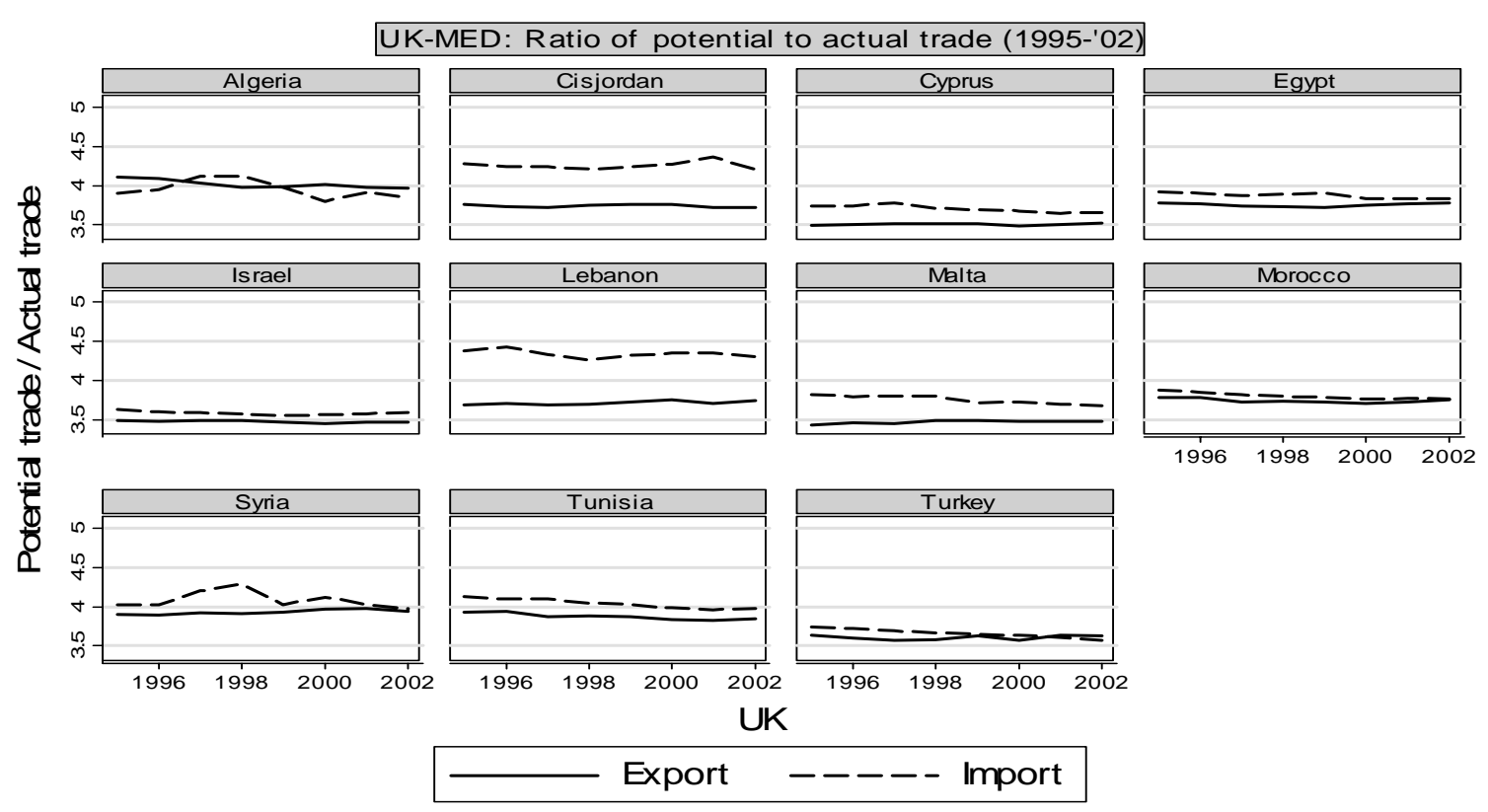

Graphs by med1

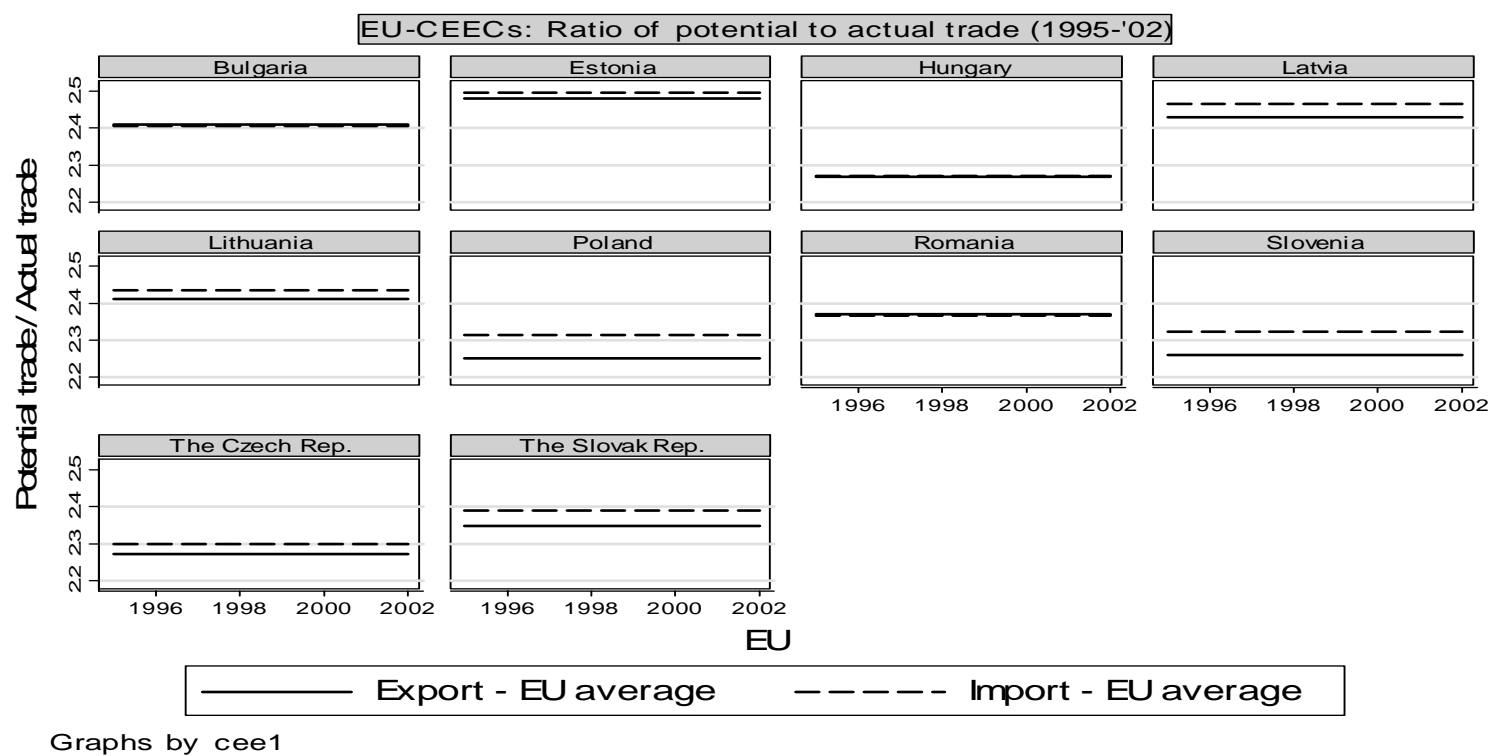

Graphs by cee1 


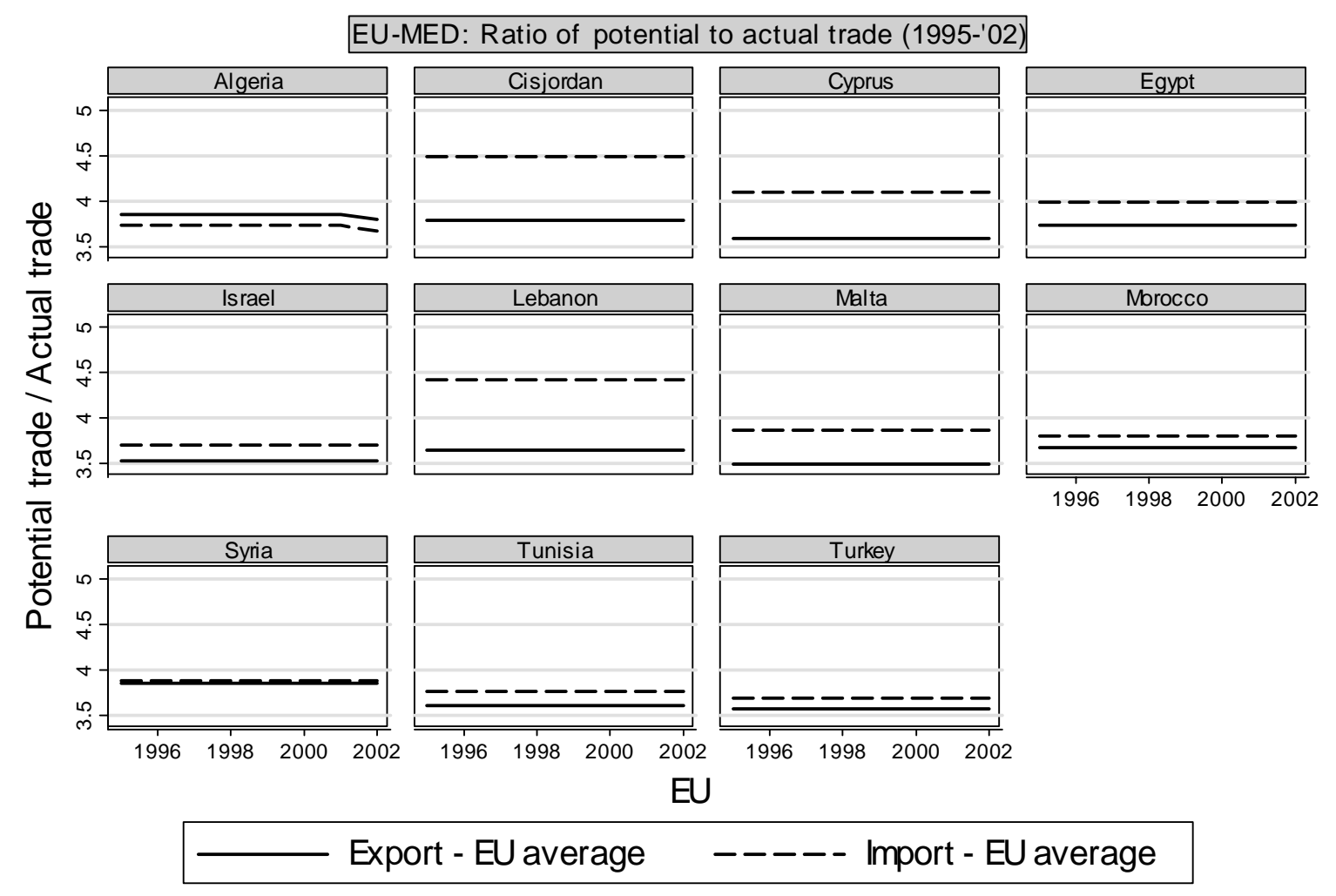

Graphs by med1 


\section{APPENDIX}

Table A1. Data source for the empirical analysis

\begin{tabular}{|l|l|l|}
\hline Variables & Source & Sample period \\
\hline $\begin{array}{l}\text { Bilateral export flows (current } \\
\text { price, US\$ millions) }\end{array}$ & $\begin{array}{l}\text { Direction of Trade Statistics, } \\
\text { International Monetary Fund, 2003 }\end{array}$ & $1995-2002$ \\
\hline $\begin{array}{l}\text { Per capita GDP (US\$ at 1995 } \\
\text { constant prices and exchange } \\
\text { rates ) }\end{array}$ & $\begin{array}{l}\text { World Bank, World Development } \\
\text { Indicators 2003 }\end{array}$ & $1995-2002$ \\
\hline Population (in millions) & $\begin{array}{l}\text { World Bank, World Development } \\
\text { Indicators 2003 }\end{array}$ & $1995-2002$ \\
\hline $\begin{array}{l}\text { Distance (straight line distance } \\
\text { in KM between capital cities) }\end{array}$ & www.wcrl.usda.gov/cec/Java & $1995-2002$ \\
\hline export (and import) unit values & $\begin{array}{l}\text { International Financial Statistics, } \\
\text { International Monetary Fund, 2003 }\end{array}$ & $1995-2002$ \\
\hline
\end{tabular}

